\title{
IDEAS RePEc Rankings Việt Nam tháng 11-2021
}

\author{
Nguyễn Quang Lộc \\ SP Jain School of Global Management, New South Wales 2141, Australia
}

Dec. 7, 2021

Ngày 6-12-2021, dữ liệu tính đến hết tháng 11 năm 2021 của IDEAS RePEc được cập nhật chính thức [1].

Dữ liệu này được trích xuất từ CSDL RePEc do Research Division of the Federal Reserve Bank of St. Louis quản trị và cập nhật hơn 25 năm qua. RePEc Rankings trích xuất cho nhiêu hạng mục, trong đó có xếp hạng các đơn vị nghiên cứu - giảng dạy về kinh tế - quản trị, và các nhà nghiên cứu.

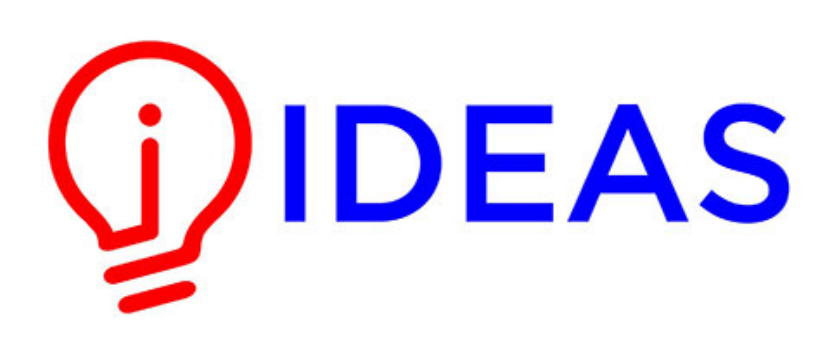

Dữ liệu mới cho biết, tính đến hết tháng 11-2021, trật tự sắp xếp các đơn vị ở tốp 5 đầu tiên không có gì thay đổi so với tháng 10-2021. Các đơn vị đó là:

1. Trường ĐH Kinh tế Tp.HCM UEH

2. Trung tâm Nghiên cứu xã hội liên ngành (ISR), Trường ĐH Phenikaa

3. Viện Nghiên cứu Phát triển Mekong (MDRI)

4. Trường Quốc tế, ĐHQG Hà Nội

5. Trường ĐH Ngoại thương

(Chi tiết 14 cơ sở trong top 25\% xem ở phụ lục.)

RePEc cho biết hiện đã có 58 cơ sở nghiên cứu - đào tạo, cùng với 191 nhà nghiên cứu, có hồ sơ đăng ký và dữ liệu được tính là đến từ Việt Nam. Theo cách tính của RePEc, với tác giả chỉ cần đăng ký có ít nhất một cơ quan hữu quan thuộc Việt Nam, là đã thuộc phạm vi địa lý quốc gia. (Một tác giả có thể đăng ký nhiều cơ quan khác nhau, đến từ các quốc gia - vùng lãnh thổ khác nhau, và có thể gán tỷ trọng đóng góp cho từng cơ quan.)

\section{References}

[1] IDEAS. (2021). Top 25\% Institutions and Economists in Viet Nam, as of November 2021. Retrieved from: https://ideas.repec.org/top/top.vietnam.html 


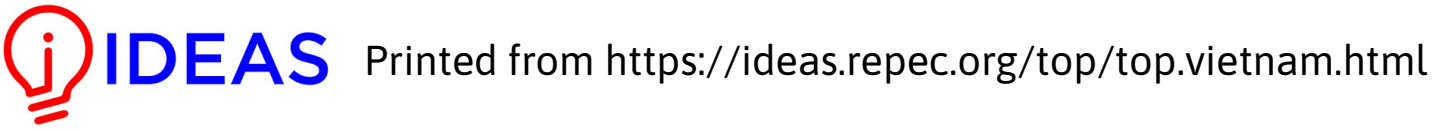

Top 25\% Institutions and Economists in Viet Nam, $a_{3}$

\begin{tabular}{|c|c|c|c|c|c|}
\hline Explan & Institutions & Institutions $10 / 10$ & Authors & Authors 10 & More \\
\hline
\end{tabular}

\section{The rankings}

Top 25\% institutions in Viet Nam, all authors, all publication years

For Viet Nam, there are 191 authors affiliated with 58 institutions. All institutions in this reg.

RankW.Rank Institution

1 [1] University of Economics Ho Chi Minh City

Ho Chi Minh City, Viet Nam

2

[2] Centre for Interdisciplinary Social Research, Phenikaa University

3

[3] $\frac{\text { Mekong Development Research Institute }}{\text { Hanoi, Viet Nam }}$

Department of Social Sciences, Economics and Management, International ؛

4

[4] National University Hanoi, Viet Nam --- [---] Institute of Business Research, University of Economics Ho Chi Minh City

5 [7] $\frac{\text { Foreign Trade University }}{\text { Hanoi, Viet Nam }}$ 6 [5] University of Economics, University of Danang

7 [6] Business and Economics Research Group, Ho Chi Minh City Open University Ho Chi Minh City, Viet Nam

8 [9] University of Economics and Business, Vietnam National University.

9

[8] School of Business and Management, RMIT University Vietnam Ho Chi Minh City, Viet Nam --- [---] $\frac{\text { School of Public Finance, University of Economics Ho Chi Minh City }}{\text { Ho Chi Minh City, Viet Nam }}$

[10] School of Public Policy and Management, Fulbright University Vietnam Ho Chi Minh City, Viet Nam 
Rank W.Rank Institution

12

[12]

Development and Policies Research Center (Depocen). Hanoi, Viet Nam

13

[13] Central Institution for Economic Management (CIEM) Hanoi, Viet Nam

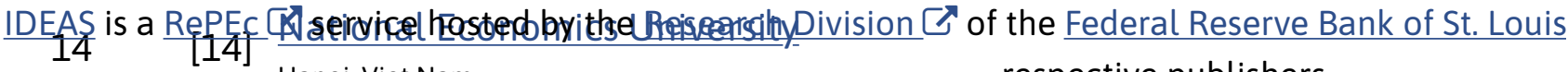
Hanoi, Viet Nam respective publishers.

We do our best, but we cannot exclude errors. 


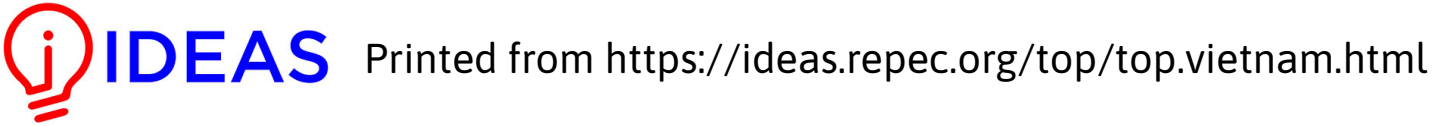

\section{Top 25\% Institutions and Economists in Viet Nam, as}

\begin{tabular}{|l|l|l|l|l|l|}
\hline Explanations & Institutions & Institutions 10/10 & Authors & Authors 10 & More \\
\hline
\end{tabular}

\section{The rankings}

Top 25\% authors in Viet Nam, all publications years

For Viet Nam, there are 191 authors affiliated with 58 institutions. All institutions in this reg. Rank W.Rank Author

$1 \quad$ Cuong Viet Nguyen

1 [2] Department of Social Sciences, Economics and Management, International School, Vietnam National Univer: Mekong Development Research Institute, Hanoi

2 [3] Xuan Vinh Vo Institute of Business Research, University of Economics Ho Chi Minh City, Ho Chi Minh City

[5] Quan Hoang Vuong

Centre for Interdisciplinary Social Research, Phenikaa University, Hanoi

4 [7] Thai-Ha Le

School of Public Policy and Management, Fulbright University Vietnam, Ho Chi Minh City

$5 \quad$ [12] Ngunyen Phu Ha

University of Economics and Business, Vietnam National University, Hanoi

6

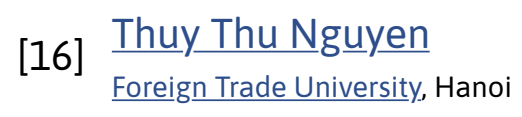

7 [6] Duc Hong Vo

Business and Economics Research Group, Ho Chi Minh City Open University, Ho Chi Minh City

8

[8] Canh Phuc Nguyen

School of Public Finance, University of Economics Ho Chi Minh City, Ho Chi Minh City

$9 \quad$ [11] Tuyen Quang Tran

Department of Social Sciences, Economics and Management, International School, Vietnam National Univer:

10 [15] Anh Ngoc Nguyen

Development and Policies Research Center (Depocen), Hanoi

11

[13] Thanh Dinh Su

School of Public Finance, University of Economics Ho Chi Minh City, Ho Chi Minh City

12

[22] Tung Lam Dang

University of Economics, University of Danang, Danang

[9] $\frac{\text { Toan Luu Duc Huynh }}{\text { University of Economics Ho Chi Minh City, Ho Chi Minh City }}$

14

[24] $\frac{\text { Tung Duc Phung }}{\text { Mekong Development Research Institute, Hanoi }}$ 
Rank W.Rank Author

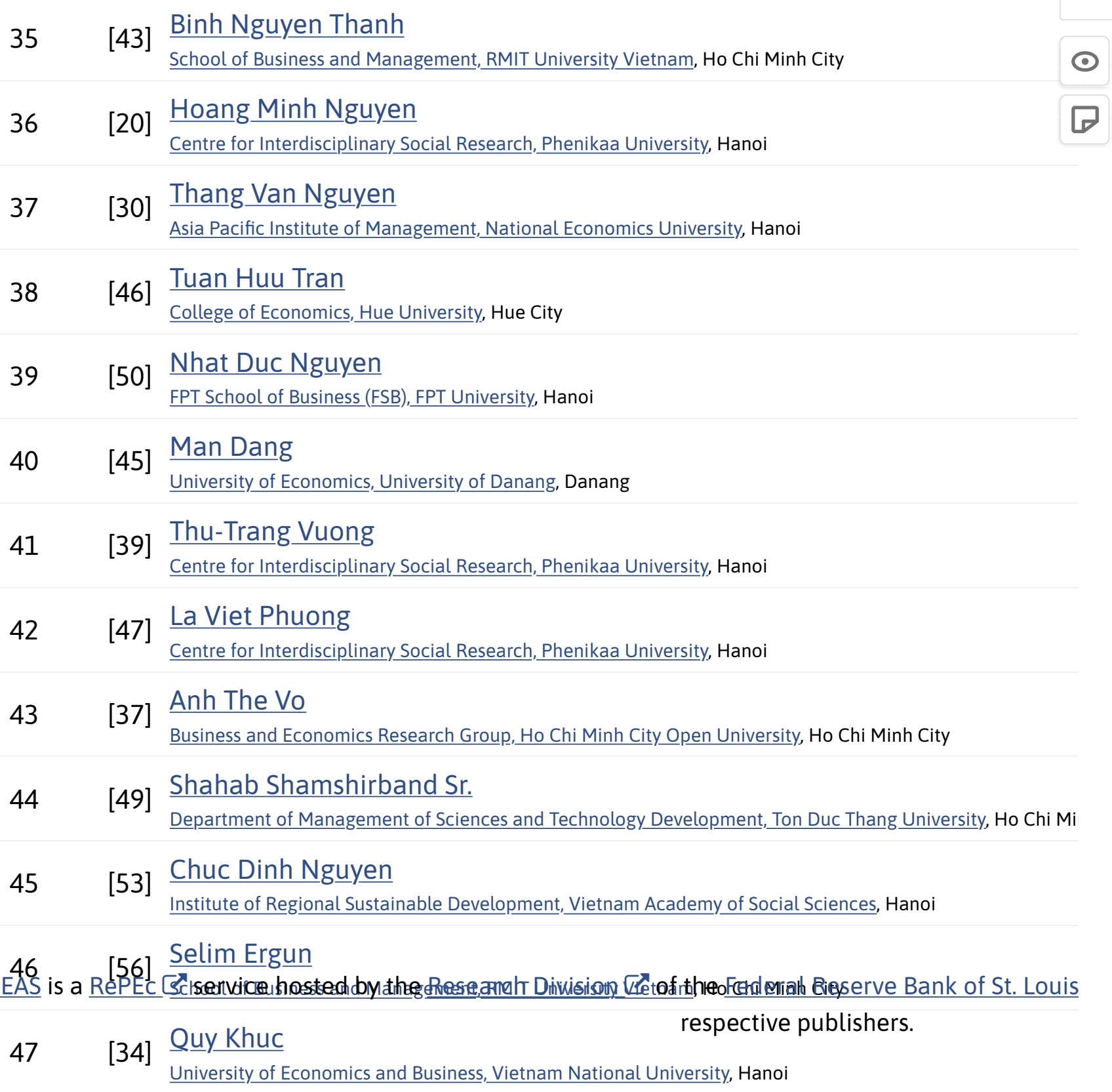

We do our best, but we cannot exclude errors. 